\title{
Comprehensive Evaluation of Soil Quality: a Case Study from a Semi-Arid Area Experiencing Coal Mine Related Subsidence in China
}

\author{
Xiaomei Gao ${ }^{1 \#}$, Yunhu Xie ${ }^{2 \#}$, Wenbang Gao ${ }^{3}$, Lixing Zhang ${ }^{1}$, \\ Yingga Wu ${ }^{1}$, Ruiping Zhou ${ }^{1 *}$ \\ ${ }^{1}$ College of Geographical Science, Inner Mongolia Normal University, Hohhot 010022, China \\ ${ }^{2}$ College of Resource \& Environmental, Baotou Teachers' College, Baotou 014030, China \\ ${ }^{3}$ Faculty of Geographical, Beijing Normal University, Beijing 100000, China
}

Received: 15 October 2020

Accepted: 20 January 2021

\begin{abstract}
Soil quality strongly influences the growth of vegetation and other environmental factors. While generating economic value, mining activities also damage soil and vegetation. Ecological restoration of areas subjected to mining activities has become a major cost borne by government agencies and mining enterprises. Restoration depends on comprehensive assessment of soil and environmental quality. This study addressed impacts of subsidence occurring around the Bulianta Coal Mine of the Shenfu coalfield in China. Using non-subsiding areas as a control, the research compared soil quality parameters defined by the Integrated Fertility Index (IFI) and Potential Ecological Risk Index (RI) frequently used in environmental monitoring and remediation. The results showed that subsided areas exhibited greater soil bulk density (SBD) and $\mathrm{pH}$ values relative to soils from areas not experiencing subsidence. Soils from subsided areas contained lower available nitrogen (AN), available potassium (AK), organic matter (SOM) relative to soils from non-subsidence areas. Different soil layers also exhibited considerable variation in available phosphorus (AP), AK, and $\mathrm{SOM}$ that attained significance at the $\mathrm{P}<0.05$ level. Soils from subsided areas showed lower concentrations of $\mathrm{Cd}, \mathrm{Cu}, \mathrm{Pb}$, and $\mathrm{Zn}$ than that measured from non-subsidence areas. The heavy metal content of non-subsided soils varied considerably with the depth of soil layer analyzed. Lead was the most abundant species of heavy metal detected in the soil of the mining area, and $\mathrm{Cd}$ showed the greatest potential risk of soil pollution in the mining area. The soil fertility index in the study area depended on subsidence, which showed some degree of spatial continuity. The subsided area showed poor soil quality and the entire area categorized as a slight potential ecological
\end{abstract}


risk. This research supports management and ecological restoration of the mining area and may serve as a reference for similarly impacted areas around the world.

Keywords: soil fertility evaluation, environmental quality evaluation, heavy metals, coal mining subsidence, semi-arid areas

\section{Introduction}

Coal is one of the top three energy sources in the world and accounts for a third of the world's energy consumption [1]. Coal resources account for $70 \%$ of China's energy resources and will thus remain an important component of China's energy portfolio for the foreseeable future [2]. At present, subsurface mining is the predominant mining methodology used to access coal resources. As one of the seven largest coal fields in the world, the Shenfu-Dongsheng coalfield exerts major impacts on its surrounding environment due to the scale of resource extraction. Impacts include ground subsidence, soil erosion, loss of soil productivity, and other forms of ecological deterioration [3-4]. Impacts associated with mining-induced land subsidence have drawn international scientific interest. Specifically, researchers have sought to understand how to restore soil function in the mining area [5].

Soil fertility depends on nutrient availability and specific environmental requirements of different types of vegetation. Soil fertility can be constrained by soil physical properties which influence the growth of vegetation [6]. Mark et al. [7] studied the effects of ground subsidence on soil properties, hydrology, and topography. Zhao et al. [8] found that coal mining subsidence caused changes in soil mechanical properties and a decrease of fine particulate matter in surface soil. Due to the arid climate and windy conditions, these impacts enhanced wind erosion of soil in the study area. Wang et al. [9] found that soil fertility in the Shendong mining area was poor due to low levels of organic matter, nitrogen, and phosphorous. Wang et al. [10] found that land subsidence around subsurface mines and other human disturbances exerted significant environmental impacts in areas with semi-arid climates. Soil quality parameters are included in soil biological and chemical indices as well as in other comprehensive estimates of environment quality [11-12].

Considerable research has focused on soil quality due to its role in environmental risk evaluation [13]. Soils can contain around $90 \%$ of environmental pollutants including heavy metal species that represent the greatest health hazards. Coal mining activities effectively expose and mobilize heavy metals through extraction, processing, transportation, and utilization [14]. Research on heavy metal pollution in soils from mining activities mainly focuses on their spatial distribution within established frameworks of hazard assessment and remediation [15-18]. Liu et al. [19] found that coal mines influenced nutrients and heavy metal content in the $0-10 \mathrm{~cm}$ soil layer around the mining area. The SOM and AN contents correlated negatively with $\mathrm{Pb}, \mathrm{Cr}, \mathrm{Cu}$, and $\mathrm{As}$ concentrations in the soil. Du et al. [20] found significant accumulations of $\mathrm{Hg}, \mathrm{Cr}, \mathrm{Zn}$, $\mathrm{As}$, and $\mathrm{Cu}$ in soil from the northern Shenmu mining area. In their study of soils surrounding coal gangue of the Shenfu mining area, Liu et al. [21] detected $\mathrm{Pb}, \mathrm{Zn}$, $\mathrm{Cu}$, and $\mathrm{Cd}$ at levels that greatly exceeded background values. Concentrations of $\mathrm{Pb}$ and $\mathrm{Cd}$ categorized as posing medium environmental risk. In recent years, methods for managing and remediating coal mining sites have transitioned from resting primarily on qualitative descriptions to resting on more quantitative evaluations. While researchers still use a range of methods, quantitative evaluation of soil quality enlists geostatistics and other numerical methods that can detect critical patterns in soil parameters [22-24]. Many studies on heavy metal contamination in soils around coal mining areas and associated risk assessment tend to use a single factor pollution index, the Nemerow index, the geoaccumulation index, a potential ecological hazard index method, or other indices [25-26], but few approaches use a suite of heavy metal measurements.

Land use planning, soil resource management, and remediation efforts all depend on accurate soil quality estimates. Restoration efforts in areas where mining has significantly damaged the environment also use soil quality estimates to manage pollution and other risks [27]. Studies on soil quality have demonstrated the interrelation of these two parameters and the need for more in depth analysis of environmental quality. Few studies have used multiple soil parameters to comprehensively evaluate pollution in areas subject to mining-induced land subsidence.

Developed and built by the Shendong Coal Group, the Bulianta Coal Mine is the largest underground coal mine in the world. The Shendong mining area experiences extensive land subsidence due to coal mining [28]. Using the Bulianta Coal Mine as a study area, this research applied fuzzy mathematics to the integrated fertility index (IFI) evaluation model and the potential ecological risk index (RI) to comprehensively evaluate soil quality and heavy metal pollution in both subsided and non-subsidence areas near and overlying the coal mine. The objectives of the study were (1) to determine sensitivity of the soil fertility index in subsided areas and (2) evaluate mining impacts through a comprehensive evaluation of soil quality in the subsided area. The results of the study provide a theoretical basis for mitigation and restoration efforts that manage impacts from resource development. 


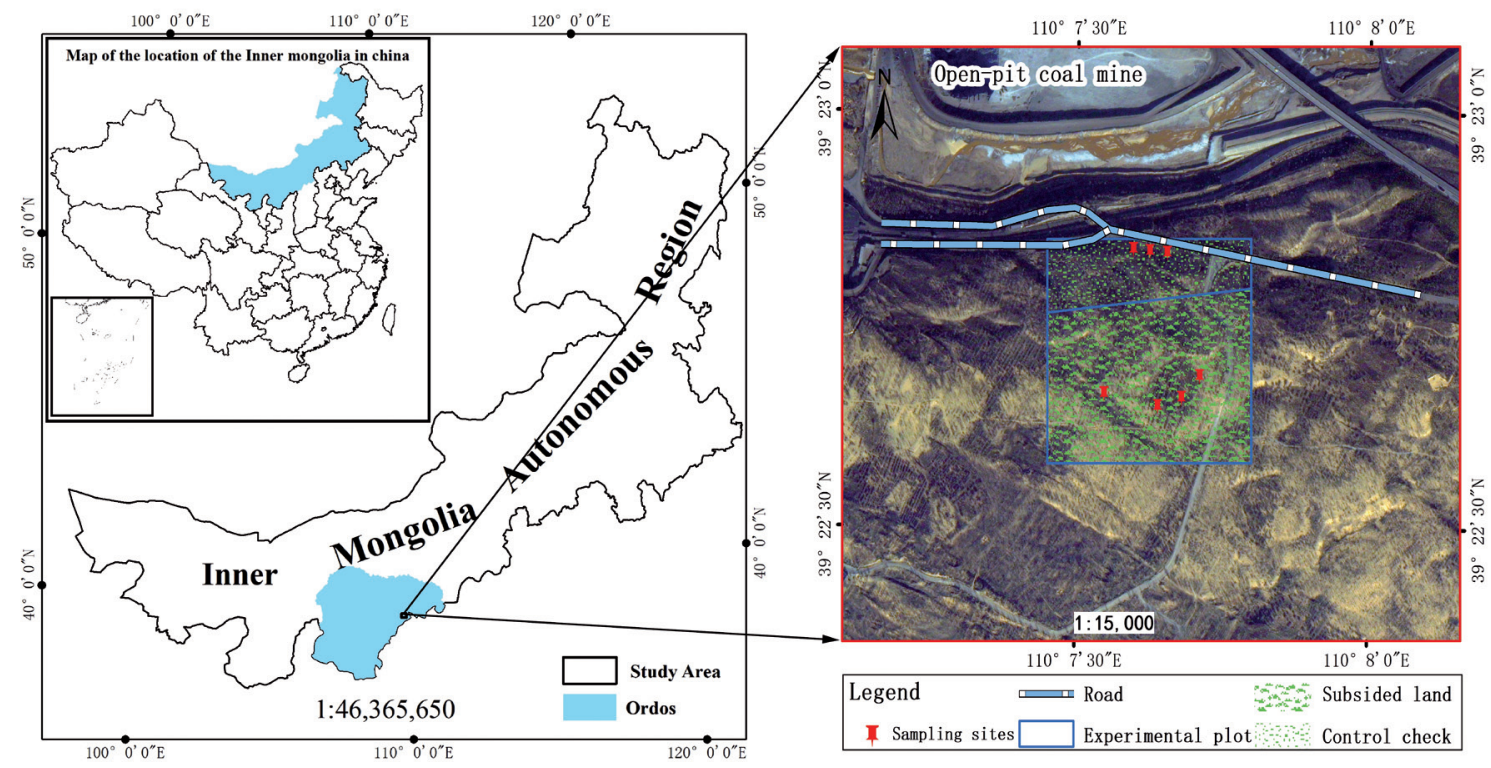

Fig. 1. Location of the study area.

\section{Materials and Methods}

\section{Study Area}

The Bulianta Coal Mine of the Shenfu Coalfield is located along the border of the Inner Mongolia Autonomous Region and Shaanxi Province (Fig. 1). It lies in a northeastern region of the large, coalrich Ordos basin along the southeastern edge of $\mathrm{Mu}$ Us Sandy Lands of the Ordos Plateau. In terms of administrative boundaries, it belongs to Wulanmulun Town of Ejin Horo Banner, Ordos. Its spans $109^{\circ} 45^{\prime}$ to $110^{\circ} 40^{\prime} \mathrm{E}$ and $38^{\circ} 50^{\prime}$ to $39^{\circ} 50^{\prime} \mathrm{N}$. With recoverable reserves of 1.24 billion tons, the Bulianta Coal Mine began operation in October 1997 and covers a $106.6 \mathrm{~km}^{2}$ area. Lying between 1100 and $1300 \mathrm{~m}$ elevation, the area experiences a typical arid to semi- arid continental climate. During the study, the annual rainfall ranged from 194.7 to $531.6 \mathrm{~mm}$, and the annual evaporation ranged from 2297.4 to $2838.7 \mathrm{~mm}$. The main types of soil in this area are aeolian soil and sandy loam, most of which takes the form of fixed and semi-fixed sand. The study area hosts sandy vegetation, low wetland vegetation, and artificial vegetation of the steppe zone. The natural vegetation consists primarily of herbaceous communities.

\section{Sample Location and Sampling}

\section{Sample Selection}

Two sites south of the Bulianta Coal Mine were selected and sampled in July 2019 due to their consistently sandy soil parent material and consistent

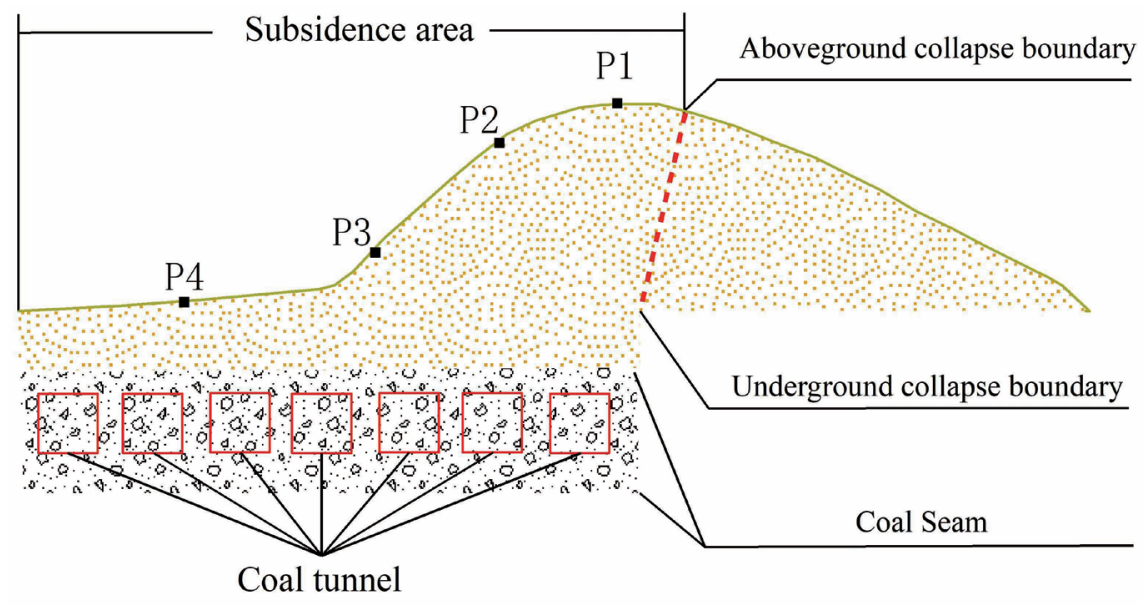

P1—Roof of slope;P2—Mid of slope;P3—Base of slope;P4—Dune lowland

Fig. 2. Diagram of sampling sites. 
underlying dune surface conditions. An area of dunes to the north showed no evidence of subsidence due to coal mining subsidence and was treated as a control area (denoted as CK or referred to as the non-subsidence area). Dunes to the south showed clear evidence of subsidence (Fig. 2) from collapse in 2004 (denoted as TX collapse and referred to as the subsided area).

\section{Soil Sampling}

Soil profiles extending $1 \mathrm{~m}$ down from a $1 \times 1 \mathrm{~m}^{2}$ area were trenched along the roof, middle, and base of the slope of a dune in the non-subsided area. Similar $1 \mathrm{~m}$ deep and $1 \times 1 \mathrm{~m}^{2}$ soil profiles were trenched along the roof, middle, and base of slopes for dunes above and below a fissure and lowland dune in a subsided zone (Fig. 3). A multi-point sampling method was used along each of the three soil profiles. Three duplicate samples were collected from the same soil profile at $0-5 \mathrm{~cm}, 5-20 \mathrm{~cm}, 20-40 \mathrm{~cm}, 40-60 \mathrm{~cm}, 60-80 \mathrm{~cm}$, and 80-100 cm depth.

\section{Experimental Methods}

Samples were transported to and analyzed at the laboratory. Soil organic matter (SOM) was determined by a potassium dichromate external heating method. Soil available nitrogen (AN) was determined by the Kjeldahl nitrogen method. Available phosphorus (AP) was determined using a $0.5 \mathrm{~mol} \cdot \mathrm{L}^{-1} \mathrm{NaHCO}^{3}$ extraction method and available potassium (AK) was determined by the flame photometric method. Soil heavy metal concentrations $(\mathrm{Cu}, \mathrm{Cd}, \mathrm{Pb}$, and $\mathrm{Zn})$ were measured by Laser-induced Breakdown Spectroscopy (LIBS). The $\mathrm{pH}$ value of soil was determined by the potential method (PXJ-1C pH meter). Soil bulk density (SBD) was determined by the cutting ring method.

\section{Statistical Analysis}

This study conducted traditional statistical analysis and principal component analysis using SPSS 25.0 and Excel 2016. Comparisons and graphs were constructed using OriginPro 9.0. Differences in soil fertility estimates for different soil layers were analyzed using one-way ANOVA and multiple comparisons (LDS). Soil fertility and heavy metal concentrations were compared and analyzed using traditional statistical methods. These included mean, minimum, maximum, skewness, kurtosis, standard deviation, and coefficient of variation. Pearson correlation coefficients were used to interpret relationships between different fertility indexes and different heavy metal pollution indexes.

\section{Comprehensive Evaluation of Soil Fertility}

\section{Types of the Membership Function and Thresholds of Soil Fertility Index}

The measured soil parameters were normalized to resolve differences in dimensions for each parameter to allow for comparisons. The fuzziness and continuity of indexes warranted standardization with a membership function. Fuzzy mathematical approaches helped establish the corresponding membership function for the fertility index [29-30]. The AN AP, AK, and SOM parameters were assigned an S-type membership function wherein membership was calculated according to formula (1):
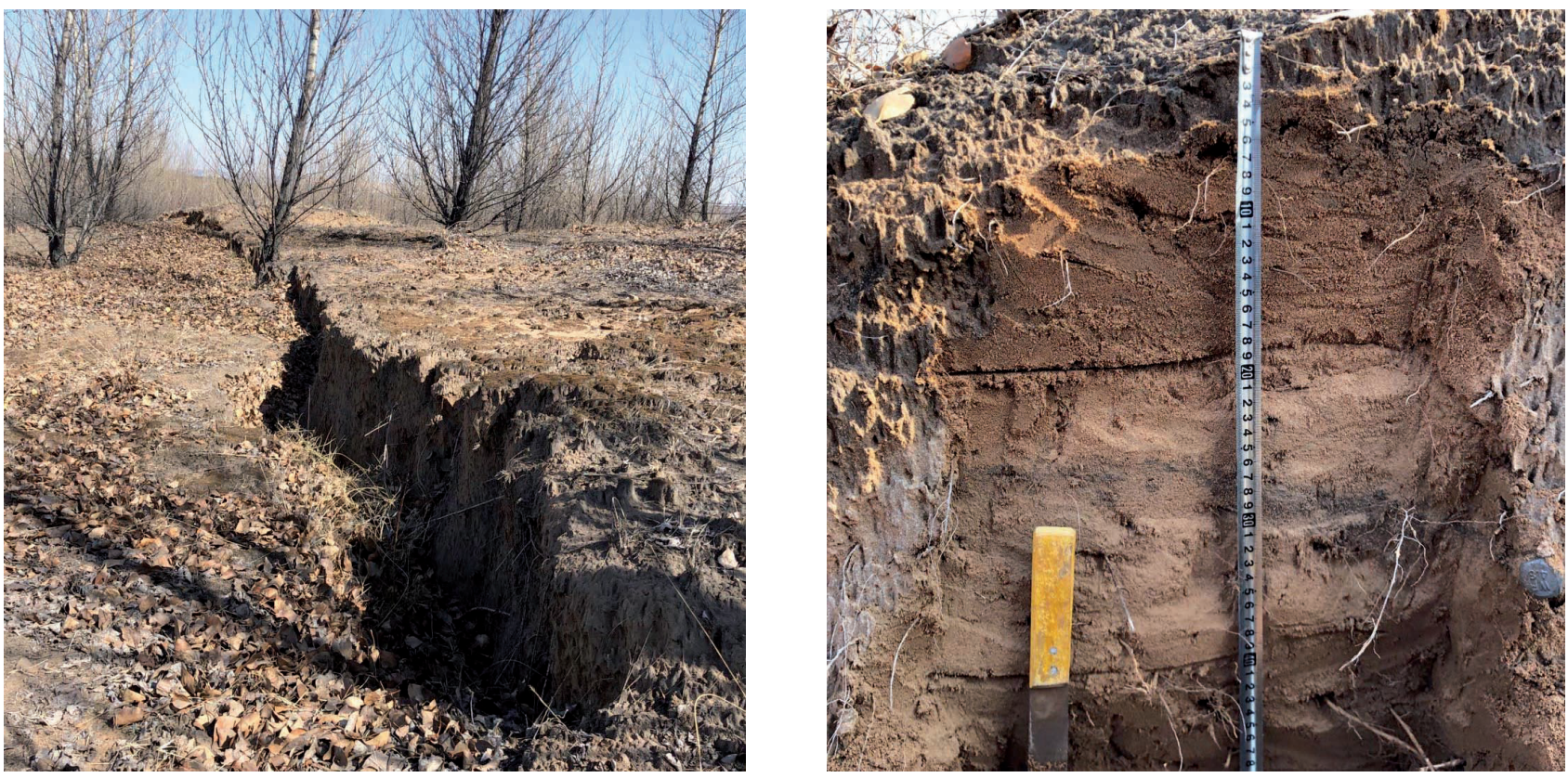

Fig. 3. An aboveground fissure indicating subsidence (left) and a soil profile (right). 
Table 1 . Types of the membership function and thresholds for soil fertility index.

\begin{tabular}{|c|c|c|c|c|c|}
\hline \multirow{2}{*}{ Types of the membership function } & \multirow{2}{*}{ Soil fertility index } & \multicolumn{4}{|c|}{ Thresholds } \\
\hline & & $x_{1}$ & $x_{2}$ & $x_{3}$ & $x_{4}$ \\
\hline \multirow{2}{*}{ Parabolic } & $\operatorname{SBD}\left(\mathrm{g} / \mathrm{cm}^{3}\right)$ & 1.25 & 1.35 & 1.45 & 1.55 \\
\hline & $\mathrm{pH}$ & 4 & 6.5 & 8 & 9 \\
\hline \multirow{4}{*}{ S-type } & $\mathrm{AN}(\mathrm{mg} / \mathrm{kg})$ & 25 & & & 40 \\
\hline & $\mathrm{AP}(\mathrm{mg} / \mathrm{kg})$ & 1 & & & 3 \\
\hline & $\mathrm{AK}(\mathrm{mg} / \mathrm{kg})$ & 20 & & & 40 \\
\hline & $\mathrm{SOM}(\mathrm{g} / \mathrm{kg})$ & 0.75 & & & 10 \\
\hline
\end{tabular}

$$
f(x)=\left\{\begin{aligned}
0.1, & x \leq x_{1} \\
0.9 \times \frac{x-\mathrm{x}_{1}}{\mathrm{x}_{4}-\mathrm{x}_{1}}+0.1, & x_{1}<x<x_{4} \\
1, & x \geq x_{4}
\end{aligned}\right.
$$

...where $f(x)$ represents the plant growth membership function of the parameter and $\mathrm{x}$ represents the measured value of the fertility index.

$\mathrm{SBD}$ and $\mathrm{pH}$ were assigned a parabolic membership function calculated as follows (2):

$$
f(x)=\left\{\begin{aligned}
0.1, & x \leq x_{1} \text { or } x \geq x_{4} \\
0.9 \times \frac{x-x_{1}}{x_{2}-x_{1}}+0.1, & x_{1}<\mathrm{x}<x_{2} \\
1, & x_{2} \leq \mathrm{x} \leq x_{3} \\
1-0.9 \times \frac{x-x_{3}}{x_{4}-x_{3}}, & x_{3}<\mathrm{x}<x_{4}
\end{aligned}\right.
$$

...where $f(x)$ represents the plant growth membership function of the parameter and $x$ represents the measured value of the fertility index.

The threshold value for membership functions was derived from a combined interpretation of literature sources [31], the soil classification standards given in the Second National Soil Survey Technical Regulations of China [32], and situational factors for the research area. Table 1 lists membership function threshold value ranges.

\section{Determination of Soil Fertility Index Weightings}

Principal component analysis (PCA) helps reduce the dimensionality of datasets by calculating a common factor variance and a set of weightings for soil parameters. Bartlett's test of sphericity applied to soil data gave a KMO value of 0.641 and sig $=0.00<0.01$ verifying that principal component analysis offers analytical benefits. The first two principal components had eigenvalues $>1$ and accounted for $60.143 \%$ of the variation. This indicates that these two component identify meaningful associations among measured parameters. Table 2 lists weightings of soil parameters for the two highest ranked components.

\section{Comprehensive Evaluation of Soil Fertility}

The Integrated Fertility Index (IFI) was calculated using the weighted sum index model provided by fuzzy mathematics [33]. Formula (3) was used to calculate IFI:

$$
\mathrm{IFI}=\sum_{n}^{i} W_{i} \cdot N_{i}
$$

...where $W_{i}$ represents the weight of the index i, $N_{i}$ represents the membership value of the index $i$, and $n$ represents the number of indices evaluated.

Table 2. PCA weightings of soil fertility index.

\begin{tabular}{|c|c|c|c|c|}
\hline \multirow{2}{*}{ Soil fertility index } & \multicolumn{2}{|c|}{ Principal component } & \multirow{2}{*}{ Communality } & \multirow{2}{*}{ Weight } \\
\cline { 2 - 5 } & 1 & 2 & 0.398 & 0.110 \\
\hline SBD & -0.615 & 0.14 & 0.765 & 0.212 \\
\hline pH & -0.302 & 0.821 & 0.597 & 0.166 \\
\hline AN & 0.402 & 0.66 & 0.399 & 0.111 \\
\hline AP & 0.631 & -0.035 & 0.734 & 0.203 \\
\hline AK & 0.835 & 0.191 & 0.715 & 0.198 \\
\hline SOM & 0.842 & -0.082 & & \\
\hline Eigenvalue & 2.435 & 1.173 & & \\
\hline Cumulative (\%) & 40.587 & 60.143 & & \\
\hline
\end{tabular}


Table 3. Pollutions levels designated by the Nemerow composite index.

\begin{tabular}{|c|c|c|}
\hline $\begin{array}{c}\text { Nemerow comprehensive } \\
\text { pollution index }\left(P_{N}\right)\end{array}$ & Grade & Pollution level \\
\hline $3<P_{N}$ & 5 & High levels of pollution \\
\hline $2<P_{N} \leq 3$ & 4 & Moderate pollution \\
\hline $1<P_{N} \leq 2$ & 3 & Light pollution \\
\hline $0.7<P_{N} \leq 1$ & 2 & Clean (warning) \\
\hline$P_{N} \leq 0.7$ & 1 & Unpolluted (safe) \\
\hline
\end{tabular}

\section{Evaluation of Soil Heavy Metal Pollution}

\section{Evaluation of Pollution Status of Soil Heavy Metals}

Single factor index evaluation represents one of the commonly used methods for evaluating degrees of pollution in soil [34]. Its formula is:

$$
P_{i}=C_{i} / S_{i}
$$

...where $P_{i}$ is the pollution index of soil pollutant $\mathrm{i}, C_{i}$ is the measured mass fraction of pollutant $\mathrm{i}$ in $\mathrm{mg} / \mathrm{kg}$, and $S_{i}$ is the evaluation standard value of pollutant $\mathrm{i}$ (Chinese Soil Environmental Quality Standard GB 15618-1995 [35], see Table 7) in $\mathrm{mg} / \mathrm{kg}$.

The Nemerow comprehensive pollution index reflects the average pollution level for each pollutant in the soil and also highlights the harm caused by the most serious pollutant to the environment [36]. Its formula is:

$$
P_{N}=\sqrt{\frac{P_{\text {imax }}^{2}+P_{\text {iave }}^{2}}{2}}
$$

...where $P_{N}$ is the comprehensive pollution index, $P_{\text {imax }}$ is the maximum value of the pollution index for each pollutant, and $P_{\text {iave }}$ is the arithmetic mean value of the pollution index for each pollutant. According to the Nemerow comprehensive pollution index, soil heavy metal pollution divides into five levels listed in Table 3.

\section{Potential Risk Associated with Soil Heavy Metals}

The Potential Ecological Risk Index (RI) was calculated to evaluate the potential risk of heavy metals in study area soils. The RI calculation runs as follows:

$$
\begin{gathered}
C_{r}^{i}=\frac{C_{i}}{C_{n}^{i}} \\
C_{p}=\sum C_{r}^{i} \\
E_{r}^{i}=T_{r}^{i} \times C_{r}^{i} \\
R I=\sum E_{r}^{i}=\sum T_{r}^{i} \times C_{r}^{i}
\end{gathered}
$$

...where, $C_{r}^{i}$ is the pollution coefficient for a given heavy metal, $C_{i}$ is the actual concentration of the heavy metal in soil, $C_{n}^{i}$ is the pollutant concentration in the original parent material or biological sediments (using background values measured from Inner Mongolian soils [37] as listed in Table 7), $C_{p}$ is the comprehensive pollution degree, $E_{r}{ }^{i}$ is the potential ecological risk coefficient of a given pollutant, and $T_{r}^{i}$ is the toxicity response coefficient of a given pollutant (the toxicity response coefficients of elements $\mathrm{Cd}, \mathrm{Pb}, \mathrm{Cu}$, and $\mathrm{Zn}$ are $30,5,5$, and 1 respectively [38]). The RI represents a multi-factor potential ecological risk index. Table 4 lists risk levels associated with RI values.

\section{Results}

\section{Soil Fertility Index in Coal Mining Subsidence Area}

Table 5 lists statistics for parameters measured from surface $(0-5 \mathrm{~cm})$ and deeper $(40-100 \mathrm{~cm})$ soils in both subsided and non-subsidence areas. Mean SBD values exceed $1.55 \mathrm{~g} / \mathrm{cm}^{3}$ and soils showed very high bulk densities. The mean $\mathrm{pH}$ value exceeded 7.5 which indicates alkaline soils. The maximum $\mathrm{pH}$ value of 9.34 came from deep samples designating those soils as strongly alkaline. In terms of SOM, the mean of surface soil ranged from $20-30 \mathrm{~g} / \mathrm{kg}$ which categorizes as the

Table 4. Risk levels for different comprehensive pollution and potential risk estimate ranges.

\begin{tabular}{|c|c|c|c|c|c|}
\hline $\begin{array}{c}\text { Comprehensive } \\
\text { pollution degree } \\
\left(C_{p}\right)\end{array}$ & Pollution level & $\begin{array}{c}\text { Potential ecologi- } \\
\text { cal risk coefficient } \\
\left(E_{r}^{i}\right)\end{array}$ & Risk level & $\begin{array}{c}\text { Potential } \\
\text { ecological risk } \\
\text { index (RI) }\end{array}$ & Risk level \\
\hline$\left(C_{p}\right)<8$ & Light pollution & $\left(E_{r}^{i}\right)<40$ & Minor ecological hazard & $\mathrm{RI}<150$ & Minor ecological hazard \\
\hline $8 \leq\left(C_{p}\right)<16$ & Moderate pollution & $40 \leq\left(E_{r}^{i}\right)<80$ & Medium ecological hazard & $150 \leq \mathrm{RI}<300$ & Medium ecological hazard \\
\hline $16 \leq\left(C_{p}\right)<32$ & Heavy pollution & $80 \leq\left(E_{r}^{i}\right)<160$ & Heavy ecological hazard & $300 \leq \mathrm{RI}<600$ & Heavy ecological hazard \\
\hline$\left(C_{p}\right) \geq 32$ & Strong pollution & $160 \leq\left(E_{r}^{i}\right)<320$ & Strong ecological hazard & $\mathrm{RI} \geq 600$ & Strong ecological hazard \\
\hline & & $\left(E_{r}^{i}\right)<320$ & Extreme ecological hazard & & \\
\hline
\end{tabular}


Table 5. Statistics for measured soil fertility index.

\begin{tabular}{|c|c|c|c|c|c|c|c|c|c|c|c|c|}
\hline \multirow{2}{*}{$\begin{array}{l}\text { Statistical } \\
\text { parameters }\end{array}$} & $\begin{array}{c}\text { Surface } \\
\text { soil }\end{array}$ & $\begin{array}{c}\text { Deep } \\
\text { soil }\end{array}$ & $\begin{array}{c}\text { Surface } \\
\text { soil }\end{array}$ & $\begin{array}{c}\text { Deep } \\
\text { soil }\end{array}$ & $\begin{array}{c}\text { Surface } \\
\text { soil }\end{array}$ & $\begin{array}{c}\text { Deep } \\
\text { soil }\end{array}$ & $\begin{array}{c}\text { Surface } \\
\text { soil }\end{array}$ & $\begin{array}{c}\text { Deep } \\
\text { soil }\end{array}$ & $\begin{array}{c}\text { Surface } \\
\text { soil }\end{array}$ & $\begin{array}{c}\text { Deep } \\
\text { soil }\end{array}$ & $\begin{array}{c}\text { Surface } \\
\text { soil }\end{array}$ & $\begin{array}{c}\text { Deep } \\
\text { soil }\end{array}$ \\
\hline Min & 1.47 & 1.51 & 7.96 & 7.06 & 25.53 & 21.14 & 2.03 & 0.84 & 22.68 & 12.73 & 3.15 & 0.32 \\
\hline Max & 1.81 & 1.81 & 9.13 & 9.34 & 35.00 & 32.74 & 4.18 & 3.62 & 61.14 & 32.29 & 57.18 & 1.63 \\
\hline Mean & 1.61 & 1.66 & 8.39 & 8.55 & 29.15 & 26.45 & 2.79 & 2.21 & 35.51 & 23.21 & 25.87 & 0.99 \\
\hline SD & 0.13 & 0.09 & 0.37 & 0.47 & 3.26 & 3.07 & 0.87 & 0.66 & 14.05 & 4.80 & 17.45 & 0.33 \\
\hline Skew. & 0.42 & -0.12 & 0.85 & -1.25 & 1.13 & 0.21 & 0.95 & 0.05 & 0.96 & -0.26 & 0.25 & -0.03 \\
\hline Kurto. & -1.40 & -0.98 & 0.13 & 3.10 & 0.23 & -0.74 & -0.98 & -0.35 & -0.59 & -0.36 & -0.65 & -0.38 \\
\hline CV & 0.08 & 0.05 & 0.04 & 0.05 & 0.11 & 0.12 & 0.31 & 0.30 & 0.40 & 0.21 & 0.67 & 0.34 \\
\hline
\end{tabular}

Surface soil occurred at 0-5 cm depth. Deep soil occurred at 40-100 cm depth. Statistics include standard deviation (SD), coefficient of variation in \% (CV), skewness (Skew), and kurtosis (Kurto.)

"medium" level in the soil nutrient classification system. The mean SOM measured from deeper soils was less than $6 \mathrm{~g} / \mathrm{kg}$. The $0.99 \mathrm{~g} / \mathrm{kg}$ value categorized as an "urgent shortage" level in the soil nutrient classification system. In terms of AN and AP, both surface and deeper soils gave mean values lower than the "emergency" level within the soil nutrient classification system, (30 $\mathrm{mg} / \mathrm{kg}$ and $3 \mathrm{mg} / \mathrm{kg}$, respectively). In terms of $\mathrm{AK}$, the surface soil gave mean values ranging from $30-50 \mathrm{~g} / \mathrm{kg}$, which qualify as the "shortage" level in the soil nutrient classification system. Deeper soils gave mean values less than $30 \mathrm{~g} / \mathrm{kg}$ which fall in the "urgent shortage" level. Surface soils showed greater spatial variation in SBD, AP, AK, and SOM than deeper layers. Surface soils showed less variation in $\mathrm{pH}$ and AN than deeper layers. Spatial variation in surface soil parameters ranked as $\mathrm{SOM}>\mathrm{AK}>\mathrm{AP}>\mathrm{AN}>\mathrm{SBD}>\mathrm{pH}$. Spatial variation in deep layer soil parameters ranked as $\mathrm{SOM}>\mathrm{AP}>\mathrm{AK}>\mathrm{AN}>\mathrm{SBD}=\mathrm{pH}$.

Single-factor variance and multiple comparison analysis (Table 6) indicate that SBD, $\mathrm{pH}, \mathrm{AN}, \mathrm{AP}, \mathrm{AK}$, and SOM vary with different soil depths. With the increase of soil depth, SBD and $\mathrm{pH}$ initially increased and then decreased in both subsided and non-subsidence areas. AP content initially decreased and then increased. AK and SOM content all showed a downward trend. AN content initially decreased and then increased in the subsided area. In the non-subsidence area, AN content

Table 6. Changes of soil fertility index measured from subsided and non-subsidence areas at different soil depths.

\begin{tabular}{|c|c|c|c|c|c|c|c|}
\hline Sample & $\begin{array}{c}\text { Soil depth } \\
(\mathrm{cm})\end{array}$ & $\begin{array}{c}\mathrm{SBD} \\
\left(\mathrm{g} / \mathrm{cm}^{3}\right)\end{array}$ & $\mathrm{pH}$ & $\begin{array}{c}\mathrm{AN} \\
(\mathrm{mg} / \mathrm{kg})\end{array}$ & $\begin{array}{c}\mathrm{AP} \\
(\mathrm{mg} / \mathrm{kg})\end{array}$ & $\begin{array}{c}\text { AK } \\
(\mathrm{mg} / \mathrm{kg})\end{array}$ & $\begin{array}{c}\text { SOM } \\
(\mathrm{g} / \mathrm{kg})\end{array}$ \\
\hline \multirow{6}{*}{$\mathrm{TX}$} & $0-5$ & $1.67 \pm 0.11 \mathrm{Aa}$ & $8.54 \pm 0.34 \mathrm{Aa}$ & $28.91 \pm 3.09 \mathrm{ABa}$ & $2.56 \pm 0.74 \mathrm{Aa}$ & $27.37 \pm 4.76 \mathrm{Aa}$ & $18.39 \pm 13.73 \mathrm{Aa}$ \\
\cline { 2 - 8 } & $5-20$ & $1.70 \pm 0.12 \mathrm{Aa}$ & $8.63 \pm 0.37 \mathrm{Aa}$ & $29.31 \pm 2.55 \mathrm{Aa}$ & $1.78 \pm 0.40 \mathrm{Ba}$ & $26.18 \pm 8.40 \mathrm{ABa}$ & $2.27 \pm 1.69 \mathrm{Ba}$ \\
\cline { 2 - 8 } & $20-40$ & $1.73 \pm 0.08 \mathrm{Aa}$ & $8.74 \pm 0.53 \mathrm{Aa}$ & $28.13 \pm 4.11 \mathrm{ABCa}$ & $2.06 \pm 0.40 \mathrm{ABa}$ & $22.90 \pm 6.52 \mathrm{~A} \mathrm{Ba}$ & $1.42 \pm 0.61 \mathrm{Ba}$ \\
\cline { 2 - 8 } & $40-60$ & $1.72 \pm 0.06 \mathrm{Aa}$ & $8.61 \pm 0.58 \mathrm{Aa}$ & $26.89 \pm 4.13 \mathrm{ABCa}$ & $1.98 \pm 0.58 \mathrm{ABa}$ & $20.78 \pm 4.95 \mathrm{Ba}$ & $1.22 \pm 0.30 \mathrm{Ba}$ \\
\cline { 2 - 8 } & $60-80$ & $1.70 \pm 0.02 \mathrm{Aa}$ & $8.55 \pm 0.47 \mathrm{Aa}$ & $25.73 \pm 2.58 \mathrm{~B} \mathrm{Ca}$ & $2.56 \pm 0.56 \mathrm{Aa}$ & $23.53 \pm 4.20 \mathrm{ABa}$ & $0.79 \pm 0.43 \mathrm{Ba}$ \\
\cline { 2 - 8 } & $80-100$ & $1.70 \pm 0.08 \mathrm{Aa}$ & $8.51 \pm 0.70 \mathrm{Aa}$ & $25.25 \pm 1.94 \mathrm{Ca}$ & $2.43 \pm 0.65 \mathrm{Aa}$ & $23.86 \pm 4.70 \mathrm{ABa}$ & $0.98 \pm 0.27 \mathrm{Ba}$ \\
\hline \multirow{5}{*}{$\mathrm{CK}$} & $0-5$ & $1.48 \pm 0.01 \mathrm{Aa}$ & $8.03 \pm 0.07 \mathrm{Ca}$ & $29.70 \pm 4.32 \mathrm{Aa}$ & $3.32 \pm 1.06 \mathrm{Aa}$ & $54.51 \pm 6.80 \mathrm{Ab}$ & $43.34 \pm 12.35 \mathrm{Aa}$ \\
\cline { 2 - 8 } & $5-20$ & $1.56 \pm 0.11 \mathrm{Aa}$ & $8.42 \pm 0.11 \mathrm{Ba}$ & $29.71 \pm 4.68 \mathrm{Aa}$ & $2.06 \pm 0.43 \mathrm{ABa}$ & $27.76 \pm 3.15 \mathrm{Ba}$ & $4.49 \pm 4.46 \mathrm{Ba}$ \\
\cline { 2 - 8 } & $20-40$ & $1.60 \pm 0.02 \mathrm{Aa}$ & $8.57 \pm 0.40 \mathrm{Aa}$ & $29.23 \pm 2.27 \mathrm{Aa}$ & $1.93 \pm 0.32 \mathrm{Ba}$ & $24.23 \pm 4.22 \mathrm{Ba}$ & $1.11 \pm 0.35 \mathrm{Ba}$ \\
\cline { 2 - 8 } & $40-60$ & $1.53 \pm 0.02 \mathrm{Ab}$ & $8.54 \pm 0.46 \mathrm{ABa}$ & $26.70 \pm 4.17 \mathrm{Aa}$ & $1.91 \pm 0.37 \mathrm{Ba}$ & $22.90 \pm 3.87 \mathrm{Ba}$ & $1.06 \pm 0.11 \mathrm{Ba}$ \\
\cline { 2 - 8 } & $60-80$ & $1.55 \pm 0.04 \mathrm{Ab}$ & $8.56 \pm 0.05 \mathrm{Aa}$ & $27.23 \pm 2.53 \mathrm{Aa}$ & $1.77 \pm 1.06 \mathrm{Ba}$ & $25.00 \pm 5.01 \mathrm{Ba}$ & $0.82 \pm 0.26 \mathrm{Ba}$ \\
\cline { 2 - 8 } & $80-100$ & $1.54 \pm 0.01 \mathrm{Ab}$ & $8.52 \pm 0.06 \mathrm{ABa}$ & $28.84 \pm 3.64 \mathrm{Aa}$ & $2.19 \pm 0.71 \mathrm{ABa}$ & $25.11 \pm 8.28 \mathrm{Ba}$ & $1.02 \pm 0.37 \mathrm{Ba}$ \\
\hline
\end{tabular}

Different capital letters indicate significant differences between different layers of TX and CK $(\mathrm{P}<0.05)$. Different lowercase letters indicate significant differences between TX and CK areas in the same soil layer $(\mathrm{P}<0.05)$. 
initially increased and then decreased. Subsidence thus strongly influences AN in the vertical direction.

For subsided areas, the greatest differences in AN values appeared between the $5-20 \mathrm{~cm}$ and $60-100 \mathrm{~cm}$ soil layers $(\mathrm{P}<0.05)$. AN did not show significant differences with depth between subsided and non-subsidence areas $(\mathrm{P}>0.05)$. For the subsided area, AP differed strongly between the $5-20 \mathrm{~cm}, 0-5 \mathrm{~cm}$, and $60-100 \mathrm{~cm}$ soil layers $(\mathrm{P}<0.05)$. For non-subsidence areas, AP did not differ significantly between the $0-5 \mathrm{~cm}$ and $20-80 \mathrm{~cm}$ soil layers $(\mathrm{P}<0.05)$. For the subsided area, AK content in subsided areas differed significantly between soil depths of $0-5 \mathrm{~cm}$ and $40-60 \mathrm{~cm}(\mathrm{P}<0.05)$. AK content in non-subsidence areas differed significantly between $0-5 \mathrm{~cm}$ and other soil depths $(\mathrm{P}<0.05)$. SOM content in both the subsided and non-subsidence areas showed significant differences between the surface layer $(0-5 \mathrm{~cm})$ and all other soil layers $(\mathrm{P}<0.05)$. In summary, excepting $\mathrm{AN}$, the $\mathrm{AP}, \mathrm{AK}$ and $\mathrm{SOM}$ measured from soils differed significantly between different soil layers $(\mathrm{P}<0.05)$. AN only differed between different soil layers in the subsided area $(\mathrm{P}<0.05)$.

On the whole, SBD measured for different depths of layers in the subsided area exceeded those measured from different layers of the non-subsidence area. Differences reached significant levels for depths of $40-60 \mathrm{~cm}(\mathrm{P}<0.05)$. Differences among different soil layers did not differ significantly between the subsided and non-subsidence areas $(\mathrm{P}>0.05)$. Above the $60 \mathrm{~cm}$ soil layer, $\mathrm{pH}$ values for all depths of the subsided area exceeded those of the non-subsidence area. Subsided and non-subsidence areas however did not show significant differences for the same soil depths $(\mathrm{P}>0.05)$. For the non-subsidence area, $\mathrm{pH}$ values for the $0-5 \mathrm{~cm}$ and $5-20 \mathrm{~cm}$ depths differed significantly from those of other soil layers $(\mathrm{P}<0.05)$. Soils from the subsided area did not show significant differences in $\mathrm{pH}$ values for different layers $(\mathrm{P}>0.05)$. Subsidence appears to influence horizontal variation in SBD and $\mathrm{pH}$. Relative to non-subsidence areas, subsided areas gave lower values of chemical parameters (AN, AK, and SOM) for each soil depth analyzed. Samples above the $20 \mathrm{~cm}$ layer for the subsided area gave higher AP content than those from the same layer of the non-subsidence area. Below the $20 \mathrm{~cm}$ layer, the subsided area gave higher AP values that those from the same layer of the nonsubsidence area. The subsided and non-subsidence areas showed no significant difference between AN, AP, and SOM measured from corresponding soil layers $(\mathrm{P}>0.05)$. However, AK did show significant differences for the $0-5 \mathrm{~cm}$ layer $(\mathrm{P}<0.05)$. This indicates that subsidence can generate horizontal variation in $\mathrm{AK}$ and AP.

\section{Analysis of Soil heavy Metal Pollution Index in Coal Mining Subsidence Area}

The heavy metal concentrations measured from surface $(0-5 \mathrm{~cm})$ and deep $(40-100 \mathrm{~cm})$ soil layers of both subsided and non-subsidence areas were interpreted with reference to background values measured for Inner Mongolia and the Chinese Soil Environmental Quality Standards (Table 7). Generally, concentrations of Cd, $\mathrm{Cu}, \mathrm{Pb}$, and $\mathrm{Zn}$ were 2-3 times higher than background values from Inner Mongolian soils for both surface and deep soil layers. This indicates heavy metal pollution of study area soils. The $\mathrm{Pb}$ and $\mathrm{Zn}$ content in the surface soil were respectively $5 \%$ and $1 \%$ higher than the national environmental standard. The $\mathrm{Cd}$ and $\mathrm{Cu}$ contents of deep soil were respectively $10 \%$ and $9 \%$ higher than the national environmental standard. While concentrations of the four heavy metals fell below

Table 7. Descriptive statistics for heavy metal concentrations in soils $(\mathrm{mg} / \mathrm{kg})$.

\begin{tabular}{|c|c|c|c|c|c|c|c|c|}
\hline Heavy metals & \multicolumn{2}{|c|}{$\mathrm{Cd}$} & \multicolumn{2}{|c|}{$\mathrm{Cu}$} & \multicolumn{2}{|c|}{$\mathrm{Pb}$} & \multicolumn{2}{|c|}{$\mathrm{Zn}$} \\
\hline $\begin{array}{l}\text { Statistical } \\
\text { parameters }\end{array}$ & $\begin{array}{l}\text { Surface } \\
\text { soil }\end{array}$ & Deep soil & $\begin{array}{l}\text { Surface } \\
\text { soil }\end{array}$ & Deep soil & $\begin{array}{l}\text { Surface } \\
\text { soil }\end{array}$ & Deep soil & $\begin{array}{l}\text { Surface } \\
\text { soil }\end{array}$ & Deep soil \\
\hline Min & 0.12 & 0.13 & 18.94 & 19.20 & 30.10 & 32.49 & 80.87 & 85.41 \\
\hline Max & 0.19 & 0.19 & 29.17 & 29.78 & 45.83 & 46.13 & 132.74 & 136.6 \\
\hline Mean & 0.14 & 0.15 & 23.47 & 24.61 & 36.80 & 38.64 & 100.5 & 108.80 \\
\hline SD & 0.02 & 0.02 & 2.98 & 3.86 & 5.99 & 5.07 & 18.86 & 20.48 \\
\hline Skew. & 1.13 & 0.19 & 0.39 & 0.20 & 0.44 & 0.14 & 0.77 & 0.18 \\
\hline Kurto. & 0.85 & -1.76 & 0.12 & -1.65 & -1.61 & -1.72 & -0.39 & -1.95 \\
\hline $\mathrm{CV}$ & 0.16 & 0.16 & 0.13 & 0.16 & 0.16 & 0.13 & 0.19 & 0.19 \\
\hline Background value & \multicolumn{2}{|c|}{0.05} & \multicolumn{2}{|c|}{13.92} & \multicolumn{2}{|c|}{16.85} & \multicolumn{2}{|c|}{56.61} \\
\hline Secondary Standard & \multicolumn{2}{|c|}{1.00} & \multicolumn{2}{|c|}{100.00} & \multicolumn{2}{|c|}{350.00} & \multicolumn{2}{|c|}{300.00} \\
\hline Primary Standard & \multicolumn{2}{|c|}{0.20} & \multicolumn{2}{|c|}{35.00} & \multicolumn{2}{|c|}{35.00} & \multicolumn{2}{|c|}{100.00} \\
\hline
\end{tabular}

The surface soil ranged from 0-5 cm depth. The deep soil ranged from 40-100 cm depth. The statistical parameters reported include standard deviation (SD), coefficient of variation in \% (CV), skewness (Skew.), and kurtosis (Kurt.). 

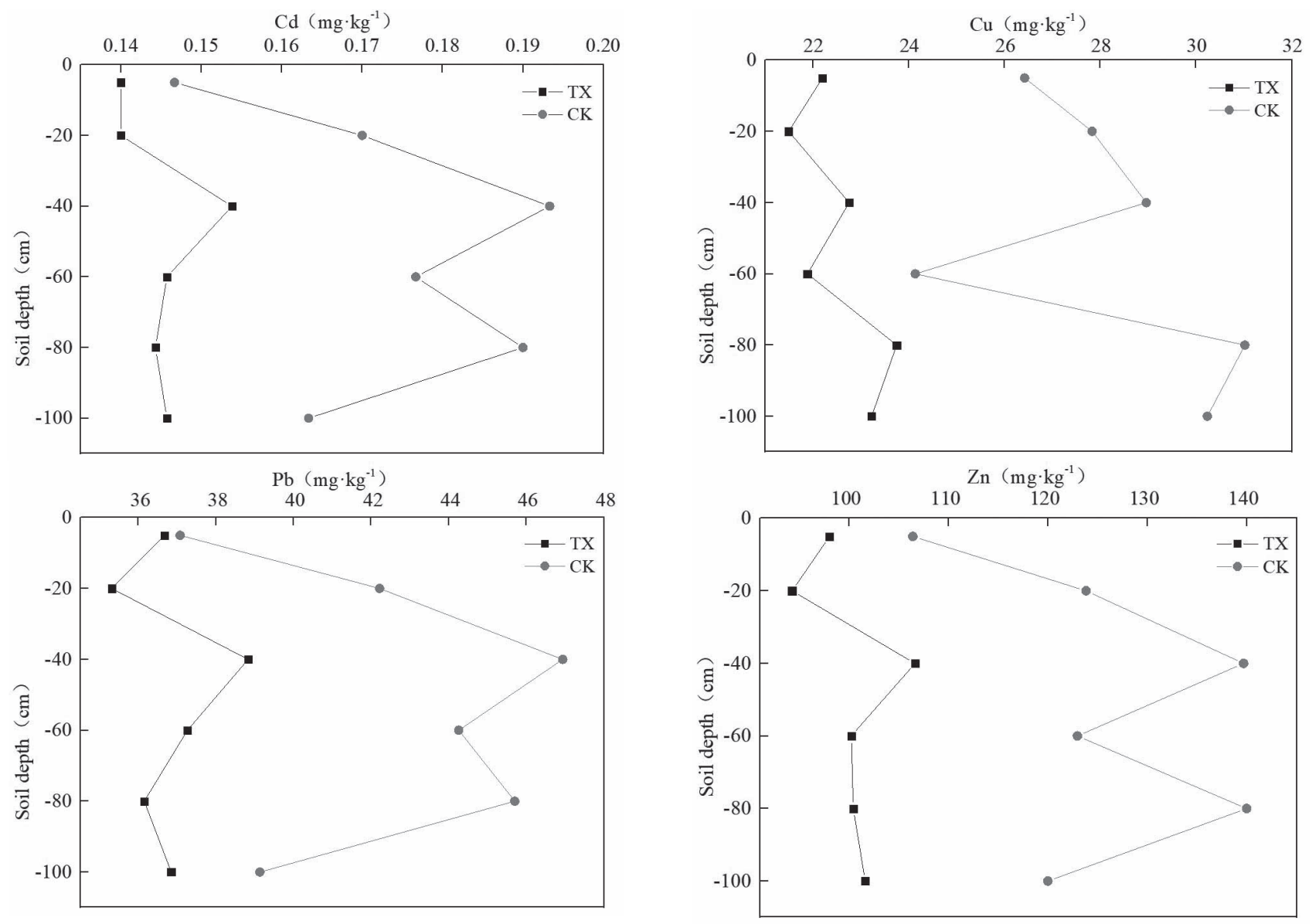

Fig. 4. Vertical distribution of heavy metal species in soils.

values listed in the national secondary environmental standards, values showed gradual increase with depth. The $\mathrm{Cd}, \mathrm{Cu}, \mathrm{Pb}$, and $\mathrm{Zn}$ concentration also showed moderate spatial variation. For surface layers, the degree of spatial variation for each element ranked as $\mathrm{Zn}>\mathrm{Cd}=\mathrm{Pb}>\mathrm{Cu}$ in surface soils. In deep soils, degree of spatial variation ranked as $\mathrm{Zn}>\mathrm{Cd}=\mathrm{Cu}>\mathrm{Pb}$. Variation in heavy metal content with depth (Fig. 4) shows that non-subsidence areas contained higher concentrations of heavy metals relative to those measured from subsided area soils. In the $0-40 \mathrm{~cm}$ soil layer, $\mathrm{Cd}, \mathrm{Cu}$, $\mathrm{Pb}$, and $\mathrm{Zn}$ increased with depth in the non-subsidence area. The $\mathrm{Cd}, \mathrm{Cu}, \mathrm{Pb}$, and $\mathrm{Zn}$ concentrations initially decreased and then increased with depth in the subsided area. For the $40-80 \mathrm{~cm}$ soil layer, $\mathrm{Cd}, \mathrm{Cu}, \mathrm{Pb}$, and $\mathrm{Zn}$ concentrations initially decreased and then increased with soil depth. Heavy metals varied greatly with the depth in soils from the non-subsidence area.

\section{Correlation of Soil Parameters and Heavy Metal Concentrations}

Table 8 lists correlations between SBD, $\mathrm{pH}, \mathrm{AN}$, $\mathrm{AP}, \mathrm{AK}$, and SOM soil parameters and heavy metal concentrations ( $\mathrm{Cd}, \mathrm{Cu}, \mathrm{Pb}$, and $\mathrm{Zn})$. This table shows that $\mathrm{pH}, \mathrm{AN}, \mathrm{AP}, \mathrm{AK}$, and SOM do not significantly correlate with the heavy metals measured from soils. The $\mathrm{Cd}, \mathrm{Pb}$, and $\mathrm{Zn}$ concentrations correlate negatively with SBD, $\mathrm{pH}, \mathrm{AP}, \mathrm{AK}$, and SOM but not AN. SBD showed significant negative correlation with heavy metal concentrations. These results indicate that soil quality parameters can be affected by heavy metal enrichment. Higher levels of heavy metal concentrations are associated with lower AP, AK, and SOM. Lower SBD values lead to greater porosity and greater potential absorption of heavy metals during soil nutrient absorption. Results also suggest that higher heavy metal concentrations in non-subsidence area soils relative to that measured in soils from subsided areas may result from lower SBD values in the latter. The SBD parameter may thus influence soil heavy metal content.

\section{Comprehensive Evaluation of Soil Quality}

The membership function clarifies functional relationships between evaluation indices and results by reconciling dimensions and scales of the evaluation index to make evaluation indices comparable. In graphical terms, points on the radar chart closer to the origin indicate lower soil quality for the index indicated by each axis. Points further from the origin indicate higher soil quality for that index. Fig. 5 shows mean membership values for the six soil fertility indices of 
Table 8. Correlations between soil fertility index and heavy metal concentrations.

\begin{tabular}{|c|c|c|c|c|c|c|}
\hline & $\mathrm{SBD}$ & $\mathrm{pH}$ & $\mathrm{AN}$ & $\mathrm{AP}$ & AK & SOM \\
\hline $\mathrm{Cd}$ & $-0.271^{*}$ & -0.092 & 0.063 & -0.201 & -0.058 & -0.178 \\
\hline $\mathrm{Cu}$ & $-0.337^{* *}$ & -0.176 & 0.140 & -0.056 & 0.177 & 0.022 \\
\hline $\mathrm{Pb}$ & $-0.283^{*}$ & -0.067 & 0.060 & -0.160 & -0.076 & -0.166 \\
\hline $\mathrm{Zn}$ & $-0.320^{*}$ & -0.112 & 0.098 & -0.160 & -0.003 & -0.134 \\
\hline
\end{tabular}

* indicates correlations significant at 0.05 level (double-tailed).

$* *$ indicates correlations significant at the 0.01 level (double-tailed).

$\mathrm{SBD}, \mathrm{pH}, \mathrm{SOM}, \mathrm{AN}$, and AK. The non-subsidence area samples gave higher values for these parameters than the subsided area. Average AP membership values for non-subsidence areas fell below those measured from subsided areas. Overall, SBD from subsided areas gave the lowest membership value.

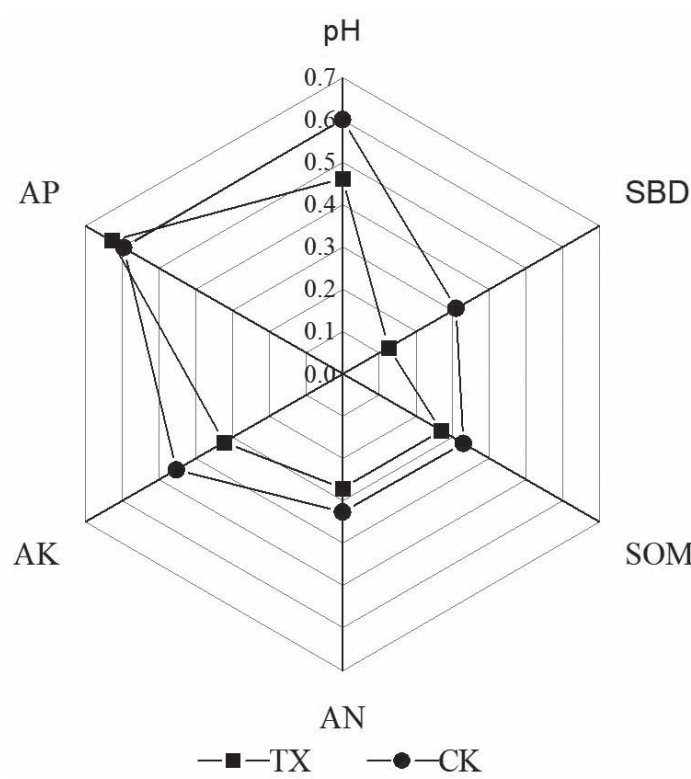

Fig. 5. Average membership values for soil fertility indices.

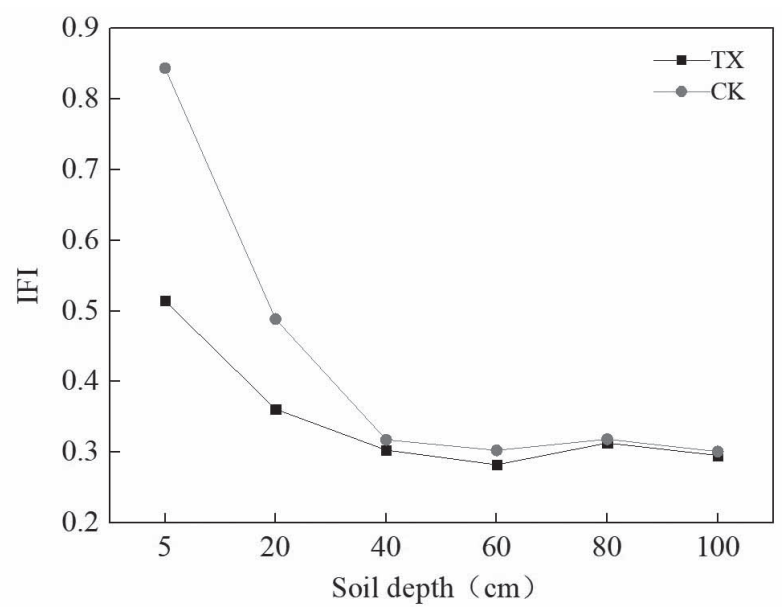

Fig. 6. Changes in IFI with soil depth.
Fig. 6 shows Integrated Fertility Index (IFI) values calculated using fuzzy mathematics for both subsided and non-subsidence areas. Above $40 \mathrm{~cm}$ depth, IFI values decline rapidly with depth for subsided and nonsubsidence areas. Below $40 \mathrm{~cm}$, the IFI shows slight decreases and occasional slight increase with depth for both subsided and non-subsidence soils. In spite of their similar patterns with depth, the non-subsidence area gave higher IFI values than those measured from the subsided area. These results suggest a longer duration of time necessary to restore surface soil quality to its original state for the subsided area. One-way ANOVA results indicate that significant differences in available soil nutrients and SOM between surface and deep layers cause the observed variation in IFI with depth. However, variation in average membership values for $\mathrm{SBD}, \mathrm{pH}$, and $\mathrm{AK}$ may also contribute to variation in IFI between subsided and non-subsidence areas.

\section{Evaluation of Soil Heavy Metal Pollution}

The Bulianta Mine is located in a semi-arid to arid steppe or desert steppe environment with low vegetation coverage and strong wind and water erosion. The environment is fragile with respect to certain perturbations. Soil types consist primarily of aeolian soil and sandy loam. The $\mathrm{pH}$ values measured from soils generally exceed 7.5, whereas Inner Mongolian soils typically exhibit relatively low $\mathrm{pH}$ values. National initiatives seek to actively monitor and manage soil erosion in the study area [39]. Using the Primary Standard as a reference value, the single factor index and the Nemerow comprehensive pollution index were used to evaluate the heavy metal pollution of soils for both subsided and non-subsidence areas (Table 9). Both subsided and non-subsidence areas showed single factor index values for elements that ranked as $\mathrm{Pb}>\mathrm{Zn}>\mathrm{Cd}>\mathrm{Cu}$. Single factor index values for $\mathrm{Cd}$ and $\mathrm{Cu}$ fell below one but exceeded one for $\mathrm{Pb}$ and $\mathrm{Zn}$. Therefore only $\mathrm{Cd}$ and $\mathrm{Cu}$ values met the Primary Standard. The Nemerow comprehensive pollution index values for the subsided area fell within a warning envelope but pollution levels still categorized as 'clean'. The comprehensive pollution index for the non-subsidence area exceeded that of the subsided area with the former categorizing as having 'light' levels of pollution. 
Table 9. Soil heavy metal pollution estimates.

\begin{tabular}{|c|c|c|c|c|c|c|}
\hline \multirow{2}{*}{ Sample } & \multicolumn{4}{|c|}{ Single-factor index $\left(P_{i}\right)$} & \multirow{2}{*}{$\begin{array}{c}\text { Nemerow comprehensive } \\
\text { pollution index }\left(P_{N}\right)\end{array}$} & Pollution level \\
\cline { 2 - 6 } & $\mathrm{Cd}$ & $\mathrm{Cu}$ & $\mathrm{Pb}$ & $\mathrm{Zn}$ & 0.97 & Clean \\
\hline $\mathrm{TX}$ & 0.72 & 0.64 & 1.05 & 1.00 & 1.16 & Light pollution \\
\hline $\mathrm{CK}$ & 0.87 & 0.80 & 1.22 & 1.25 & \\
\hline
\end{tabular}

Table 10. Estimates of potential ecological risk based on heavy metal values.

\begin{tabular}{|c|c|c|c|c|c|c|}
\hline \multirow{2}{*}{ Sample } & \multicolumn{3}{|c|}{ Potential ecological risk coefficient $\left(E_{r}^{i}\right)$} & Comprehensive pollution degree \\
\cline { 2 - 6 } & $\mathrm{Cd}$ & $\mathrm{Cu}$ & $\mathrm{Pb}$ & $\mathrm{Zn}$ & $\begin{array}{c}\text { Potential ecological risk index } \\
(\mathrm{RI})\end{array}$ \\
\hline \multirow{2}{*}{$\mathrm{TX}$} & 86.95 & 8.10 & 10.93 & 1.77 & 8.47 & 107.76 \\
\cline { 2 - 7 } & Heavy & Minor & Minor & Minor & Medium & Minor \\
\hline \multirow{2}{*}{$\mathrm{CK}$} & 104.00 & 10.09 & 12.63 & 2.22 & 10.23 & 128.94 \\
\cline { 2 - 7 } & Heavy & Minor & Minor & Minor & Medium & Minor \\
\hline
\end{tabular}

Table 10 lists potential ecological risk index estimates for soils from both subsided and non-subsidence areas. The potential ecological risk coefficient for elements ranked as $\mathrm{Cd}>\mathrm{Pb}>\mathrm{Cu}>\mathrm{Zn}$. Of these, $\mathrm{Cd}$ gave the largest potential ecological risk coefficient for both subsided and non-subsidence areas. The potential ecological risk coefficients for $\mathrm{Cd}$ categorized as a 'heavy' ecological hazard while coefficients for $\mathrm{Pb}, \mathrm{Cu}$, and $\mathrm{Zn}$ categorized as 'minor' ecological hazards. The $\mathrm{Cd}$ concentrations in soils analyzed significantly exceeded background values for Inner Mongolian soils and Cd also carried a higher biotoxicity coefficient. In summary, risk indices indicate minor ecological hazards for the study area while the comprehensive pollution degree indicates a medium level ecological hazard. Cadmium in soils contributes to the elevated potential ecological risk. The above results also show that heavy metals in the study area soils remain elevated even after 15 years of restoration. The long term persistence of hazards require monitoring and further mitigation.

\section{Discussions}

\section{Effects of Subsidence on Soil Fertility Index}

Soil in subsided or subsiding areas settles due to gravity, ground strength, and soil properties. Wind and water erosion can fill fissures and small gaps in the soil and increase compaction [40]. The research described here found that SBD in the subsided area exceeded that measured from the non-subsidence area. Differences increased with increasing soil depth. Wang et al. [41] described similar changes in soil physical and chemical properties after subsidence associated with the northern Shenmu mining area. In their study, soils from the subsided area exhibited higher $\mathrm{pH}$ values than those measured from the non-subsidence area. The $\mathrm{pH}$ of deeper soil exceeded values of 8.5 exhibiting an alkaline chemistry similar to that described here. Alkalinity may result from lack of rainfall and high evaporation in arid and semi-arid areas. Salts donate hydroxide ions that accumulate in soil and groundwater. Fissures from subsided and subsiding areas can intensify soil moisture loss and thereby enhance soil salinization [42].

In this study, AN, AP, AK, and SOM in soil collected from subsided areas fell below that measured from soils collected from non-subsidence areas. The low vegetation coverage for subsided areas may limit sources of SOM in the soil, reduce other soil nutrients, and promote soil degradation [43]. SOM content in the surface soil significantly exceeds that measured from deeper layers. Accumulation of SOM in the surface soil due to vegetation cover may contribute to this effect. Restricted microbial activity in deeper layers may further hinder decomposition of soil organic matter [44]. $\mathrm{AK}$ and SOM contents tend to decrease with increasing soil depth. Meanwhile AP content increases with soil depth perhaps due to the poor phosphate fixation and buffer capacity of the sandy soils that characterize the study area. These limit AP transfer into deep soils with surface cracks [45]. For this study, soils were sampled during the rainy season which may have caused the initial decrease and subsequent increase in $\mathrm{AN}$ with depth observed among soils in the subsided area. This pattern contrasted that observed for the non-subsidence areas, which showed an initial increase and subsequent decrease in AN with depth. Rainfall may have enhanced formation of subsidence cracks which in turn enhanced leaching of nitrogen and transport to deeper soil layers.

\section{Effects of Subsidence on Soil Heavy Metal Content}

Presently, most studies focus on heavy metal pollution in the form of $\mathrm{Cu}, \mathrm{Zn}, \mathrm{Pb}, \mathrm{Cd}, \mathrm{Ni}$, and $\mathrm{Cr}$ 
concentrations in soils around mining areas. However, different studies have reported differing degrees of accumulation and impact [46]. This study reports soil $\mathrm{Cd}, \mathrm{Cu}, \mathrm{Pb}$, and $\mathrm{Zn}$ concentrations that all exceeded background values for Inner Mongolian soils by a factor of 2-3. Results reported here also exceeded those reported for a cultivated soil near the Daliuta Coal Mine [47] by a factor of 2-3. Generally speaking, after adsorption by clay minerals in surface layers, heavy metals do not tend to migrate [48]. However, soils analyzed here show increasing heavy metal concentrations with depth possibly due to strong wind and water erosion. Transport and deposition of coal dust due to wind action may increase heavy metal input to soils which in turn experienced enhanced heavy metal leaching [49]. This study found lower heavy metal concentrations in soils from subsided areas relative to those analyzed from non-subsidence areas. Transport routes north of the slope analyzed as the non-subsidence area may have contributed to this effect. Along with transport vehicles, coal gangue in the mining area may have served as a source of wind-transported coal dust.

\section{Conclusions}

(1) Mean SBD values for the study area exceeded $1.55 \mathrm{~g} / \mathrm{cm}^{3}$. Soils were compacted and showed $\mathrm{pH}$ values ranging from 7.06 to 9.34. The AN, AP, AK, and SOM contents of deeper soil layers place them at "urgent shortage" levels according to soil standards. Soil profiles showed significant variation in AP, AK, and SOM with depth $(\mathrm{P}<0.05)$. The AP, AK, and SOM contents tend to decrease with depth. The AN, AP, $\mathrm{AK}$, and SOM contents for the subsided area fell below values measured for the non-subsidence area. Samples from a given soil layer depth did not show significant variation in $\mathrm{pH}, \mathrm{AN}, \mathrm{AP}$, or $\mathrm{SOM}$ between the subsided and the non-subsidence area $(\mathrm{P}>0.05)$.

(2) The $\mathrm{Cd}, \mathrm{Cu}, \mathrm{Pb}$, and $\mathrm{Zn}$ concentrations measured from the study area all exceeded the natural background values for Inner Mongolian soils by a factor of 2-3. Heavy metals did not exceed secondary soil environmental quality standards however. Soils from the subsided area showed lower $\mathrm{Cd}, \mathrm{Cu}, \mathrm{Pb}$, and $\mathrm{Zn}$ concentrations than the non-subsidence area. Soils from both subsided and non-subsidence areas showed an inflection point with sharp decreases in heavy metal concentrations above $40 \mathrm{~cm}$ depth and more gradual variation below this depth.

(3) Soils from the subsided area gave IFI values from $0.17-0.41$, while those from the non-subsidence area gave IFI values from $0.42-0.85$. The subsided areas gave relatively poor estimates of soil quality. The $\mathrm{Cd}$ concentrations measured from the study area gave the largest potential ecological risk coefficients. Parameters from the subsided and non-subsidence areas gave Potential Ecological Risk Index values of 107.76 and
128.94, respectively, which indicate minor ecological hazard.

\section{Acknowledgement}

This research was financially supported by the sub-project of Inner Mongolia Autonomous Region major scientific and technological program of Research on Soil Quality Evolution and Control Mechanism of Coal Resource Exploitation in Windstorm Area [zdzx2018058], the Inner Mongolia Natural Science Foundation Program of Study on the Influence Mechanism of Wind Power Station on Vegetation in Grassland Area of Northern, China [2018MS04009] and the Research and Innovation Fund for Postgraduates of Inner Mongolia Normal University [CXJJS19144].

\section{Conflicts of Interest}

The authors declare no conflict of interest.

\section{References}

1. WANG NUO, ZHANG JIN, WU DI, ZHAO WEI-JIE. The temporal and spatial patterns and causes of coal resource flow in the world, Journal of Natural Resources, 34 (03), 487, 2019.

2. YANG ZHI, LI WEN-PING, LI XIAO-QIN, WANG QI-QING, HE JIANG-HUI Assessment of eco-geoenvironment quality using multivariate data: A case study in a coal mining area of Western China, Ecological Indicators, 107, 2019.

3. WANG XU-FENG, ZHANG DONG-SHENG, ZHANG CHENG-GUO, FAN GANG-WEI Mechanism of mininginduced slope movement for gullies overlaying shallow coal seams, Journal of Mountain Science, 10 (03), 388, 2013.

4. GUO QIAO-LING, MA ZHI-HUA, SU NING, YANG YUN-SONG, HAN ZHEN-YING Effects of cracks in coal mining subsidence area on soil moisture content in Shenfu-Dongsheng coalfield, Science of Soil and Water Conservation, 17 (01), 109, 2019.

5. HU ZHEN-QI, LONG JING-HUA, WANG XINJING Selfhealing, natural restoration and artificial restoration of ecological environmental for coal mining, Journal of China Coal Society, 39 (8), 1751, 2014.

6. LUO DONG-QI, BAI JIE, XIE DE-TI Research on evaluation norm and method of soil fertility, Soil and Environmental Sciences, 11 (2), 202, 2002.

7. ALEX MARK LECHNER, THOMAS BAUMGART, PHIL MATTHEW, VANESSA GLENN The Impact of Underground Longwall Mining on Prime Agricultural Land: A Review and Research Agenda, Land Degradation \& Development, 27 (6), 1650, 2014.

8. ZHAO GUO-PING, ZHU JIAN-JUN, ZHANG JIPING, XU WEI-ZHOU Discussion on the several ecological problems caused by coal mining subsidence in Shenfu coalfield, Journal of Arid Land Resources and Environment, 31 (9), 103, 2017.

9. WANG YI, LIU MEI-YING, CHEN SHI-CHAO, LIU KE, HE XIAO, HU CHUN-YUAN, HAO YU-FU Preliminary 
study on soil fertility characteristics in Shen-Dong mining area, Journal of Arid Land Resources and Environment, 9, 63, 2014.

10. WANG QI, QUAN ZHAN-JUN, HAN YU, FU MENGDI, YE YAO Variation of Vegetation Diversity and Its Soil Relationship with Soil Physical and Chemical Property in Lands of Different Geomorphic Types in Coal Mining Subsidence Area, Acta Botanica Boreali-Occidentalia Sinica, 34 (08), 1642, 2014.

11. GAO TAN, LI JIANG-RONG, LU JIE, ZHENG WEI-LIE Soil nutrient characteristics of Abies georgei var. smithii forest and its cutting site in Sejila Mountain, Journal of Northwest A \& F University (Natural Science Edition), 48 (2), 1, 2020.

12. YAO RONG-JIANG, YANG JING-SONG, GAO PENG, ZHANG JIAN-BING, JIN WEN-HUI Determining minimum data set for soil quality assessment of typical salt-affected farmland in the coastal reclamation area, Soil and Tillage Research, 128 (3), 137, 2013.

13. ZHOU DONG-MEI, WANG SHEN-QIANG, CHEN HUAI-MAN Interaction of Organic Pollutants and Heavy Metal in Soil, Soil and Environmental Sciences, 2, 143, 2000.

14. CUI LONG-PENG, BAI JIAN-FENG, SHI YONGHONG, YAN SHI-LONG, HUANG WEN-HUI, TANG XIU-YI Heavy metals in soil contaminated by coal mining activity, Acta Pedologica Sinica, 6, 896, 2004.

15. LI FEI, CAI YING, ZHANG JING-DONG Spatial Characteristics, Health Risk Assessment, and Sustainable Management of Heavy Metals and Metalloids in Soils from Central China, Sustainability, 10 (2), 91, 2018.

16. LI XIN-XIN, WANG XIN-LEI, CHEN YUE-DONG, YANG XIAO-YONG, CUI ZHAO-JIE Optimization of combined phytoremediation for heavy metal contaminated mine tailings by a field-scale orthogonal experiment, Ecotoxicology and Environmental Safety, 168, 1, 2019.

17. LIN WEN-TING, WU KANG-MING, LAO ZHI-LANG, HU WEI, LIN BO-JI, LI YAN-LIANG, FAN HONG-BO, HU JUN-JIE Assessment of trace metal contamination and ecological risk in the forest ecosystem of indexing mining area in northeast Jiangxi Province, China, Ecotoxicology and Environmental Safety, 167, 76, 2019.

18. MORALES RUANO S., MARTNÍ-PEINADO F.J., ESTEPA MOLINA C.M., BAGUR-GONZÁLEZ M.G. A quick methodology for the evaluation of preliminary toxicity levels in soil samples associated to potentially heavy-metal pollution in an abandoned ore mining site, Chemosphere, 222, 345, 2019.

19. LIU JUN, ZHANG CHENG-FU, SUN DONG-JIE, JING YAN-BIN The impact of coal mining on soil nutrients and heavy metals in rainfed farmland in arid grassland area, Journal of Ecology and Rural Environment, 35 (7), 909, 2019.

20. DU HUA-DONG, LIU YU-QING, HAN YING, DING YI Contamination characteristics and ecological risk evaluation of soil heavy meatal in national shenmu coal mining area, Environmental Engineering, 35 (11), 155, 2017.

21. LIU YUE, HAN XUEFENG, NIU HONG, ZHANG LEI Assessment of periphery soil heavy metal pollution of coal gangue in Shen-Fu mining area, Journal of Liaoning Technical University: Natural Science, 34 (9), 1021, 2015.

22. YANG WEN-NA, REN JIA-XIN, LI ZHONG-YI, XU YI, LI ZHEN-LUN, HE BING-HUI Soil Fertility in Karst Regions with Analysis of Principal Component and
Fuzzy Synthetic Evaluation, Southwest China Journal of Agricultural Sciences, 32 (6), 1307, 2019.

23. WANG ZHEN-NAN, ZHANG QING-PING, LU JIAOYUN, YANG MEI, YANG HUI-MIN Assessment of soil fertility in lucerne stands of different ages using grey correlative degree analysis, Pratacultural Science, 32 (8), 1230, 2015.

24. CHU ZHUO-DONG, LIU WEN-JU, XIAO YA-BING, ZHU YONG-GUAN, ZHENG WEN-JIE, DUAN YUHANG Survey and Assessment of Heavy Metals in Soils and Herbal Medicines from Chinese Herbal Medicine Cultivated Regions, Environmental Science, 31 (6), 1600, 2010.

25. LIU SHI-LIANG, GUO XU-DONG, YAO XI-JUN, TIAN YUN-YU, ZHAO WEN-WU, AN NAN-NAN Analysis of the influential factors and the heavy metal content distribution in the soil in prairie coal-mining regions, Journal of Safety and Environment, 16 (3), 320, 2016.

26. FENG QIAN-WEI, WANG BING, MA XIAN-JIE, JIANG ZONG-HONG, CHEN MIAO Pollution Characteristics and Source Analysis of Heavy Metals in Soils of Typical Lead-zinc Mining Areas in Northwest Guizhou,China, Bulletin of Mineralogy, Petrology and Geochemistry, 39 (04), 863, 2020.

27. GUO BIN, XU HUO-ZHONG, PAN YING-JIE, TANG SHI-QIN, LIN YI-CHENG, LI HUA, FU QING-LIN Comprehensive Assessment of Soil Fertility and Soil Environmental Quality of Vegetable and Tea Bases in Li Shui, Journal of Nuclear Agricultural Sciences, 32 (06), 1239, 2018.

28. LIU ZHAO-XIANG Study on Geological Environment Reconstruction of Drought Glassland Region in Bulianta Coal Mine, Safety in Coal Mines, 48 (S1), 90, 2017.

29. WANG JIAN-GUO, YANG LING-ZHANG, SHAN YANHONG Application of fuzzy Mathematics to soil Quality Evaluation, Acta Pedologica Sinica, 38 (2), 176, 2001.

30. WU YU-HONG, TIAN XIAO-HONG, TONG YANAN, NAN XIONG-XIONG, ZHOU MI, HOU YONGHUI Assessment of integrated soil fertility index based on principal components analysis, Chinese Journal of Ecology, 29 (1), 173, 2010.

31. LIN SHUAI, YAN WEI, JIA XUE-WEN, YAN HAI-XIA, LIU ZE-HAO, BAI SHU-LAN Comprehensive Evaluate of Soil Fertility of Different Forests in MU Us Sandy Land, Northern Horticulture, 15, 91, 2019.

32. The technical specification for the second national soil survey, 1996.

33. WANG ZHUO-LI, GENG PENG-XV, WANG HAI-RONG Comprehensive assessment and tendency analysis of soil fertility of reclaimed land based on fuzzy mathematics, China Mining Magazine, 20 (4), 51, 2011.

34. SUN XIAN-BIN, LI YU-CHENG The Spatial Distribution of Soil Heavy Metals and Variation Characteristics of Datong Abandoned Coal Mine Area in Huainan City, Scientia Geographic Sinica, 33 (10), 1238, 2013.

35. State Environmental Protection Administration. National Standards Of P.R.C of Environmental quality standard for soils (GB15618-1995), Beijing: China Environmental Science Press, 1995.

36. SI WAN-TONG, DAI JING, ZHAO XUE-BO, LIU JUMEI, ZHANG CHUAN, WANG JIAN-YING, ZHANG XUE-FENG Ecological risk assessment of heavy metal pollution in the rare tailings wetland soils, Yellow River, 39 (8), 71, 2017.

37. CHAI SHI-WEI, WEN YAN-MAO, ZHANG YA-LEI, ZHAO JIAN-FU Application of index of geoaccumulation 
to pollution evaluation of heavy metals in soil, Journal of Tongji University: Natural Science, 34 (12), 1657, 2006.

38. HAKANSON LARS An ecological risk index for aquatic pollution control.a sedimentological approach, Water Research, 14 (8), 975, 1980.

39. ZHANG DONG-SHENG, FAN GANG-WEI, MA LIQIANG, WANG AN, LIU YU-DE Harmony of large-scale underground mining and surface ecological environment protection in desert district - a case study in Shendong mining area, northwest of China, Procedia Earth and Planetary Science, 1 (1), 1114, 2009.

40. LIU ZHE-RONG, YAN LING, HE XIAO, BAO LI-YING, LIU GUAN-ZHI Effects of mining subsidence on physical and chemical properties of soil in the subsided land of the Daliuta Mining Area, Journal of Arid Land Resources and Environment, 28 (11), 133, 2014.

41. WANG SHUANG-MING, DU HUA-DONG, WANG SHENG-QUAN Analysis of damage process and mechanism for plant community and soil properties at northern Shenmu subsidence mining area, Journal of China Coal Society, 42 (1), 17, 2017.

42. ZHANG YAN-XU, BI YIN-LI, WANG ZHI-GANG, QIU LANG, SUN HUAN, CAI YUN Effects of coal mining subsidence on the rhizosphere environment of Artemisia ordosica in $\mathrm{Mu}$ Us sandland, northwest China, Journal of Mining Science and Technology, 1 (2), 131, 2016.

43. SHI PEI-LI, ZHANG YU-XIU, HU ZHEN-QI, MA KANG, YU BING-BING Influence mechanism of coal mining subsidence on soil quality and restoration measures in west China aeolian sand area, Journal of University of Chinese Academy of Sciences, 34 (3), 318, 2017.

44. WANG QI, QUAN ZHAN-JUN, HAN YU, FU MENGDI, YE YAO Changes of Soil Physical And Chemical Properties Under Different Coal Mining Subsidence Years In Windy Desert Area, Journal of soil and water conservation, 28 (02), 118, 2014.

45. ZANG YIN-TONG, WANG JI, DING GUO-DONG, GAO YONG, HE XIAO, YAN LIN, HE ZHI, NA QIN, GONG PING, REN YU Variation of physiochemical properties of aeolian sandy soil at coal mining subsidence and its evaluation, Acta Pedologica Sinica, 47 (02), 262, 2010.

46. WANG LI, WANG LI, HE WEN-XIANG, WANG MEI, YI XIAO-BO Contaminate characteristic of heavy metals in soils in Shenmu mining area, ecology and environmental sciences, 20 (Z2), 1343, 2011.

47. XU YOU-NING, CHEN SHE-BIN, CHEN HUA-QING, YUAN HAN-CHUN Study on soil heavy metals pollution in daliuta coal mine area, China Mining Magazine, 7, 47, 2007.

48. GUO WEI, ZHAO REN-XIN, ZHANG JUN, BAO YUYING, WANG HONG, YANG MING,SUN XIAOLI, JIN FAN Distribution characteristic and assessment of soil heavy metal pollution in the iron mining of Baotou in Inner Mongolia, Huan jing ke xue, 32 (10), 3099, 2011.

49. SHI ZHAN-FEI, WANG LI Contents of Soil Heavy Metals and Evaluation on the Potential Pollution Risk in Shenmu Mining Area, Journal of Agro-Environment Science, 32 (06), 1150, 2013. 